\title{
"LUÍS SOARES", A ESCOLHA FEMININA E O NOVO OBJETO DO AMOR
}

\author{
NAIARA SANTANA PITA ${ }^{1}$ \\ ${ }^{1}$ Universidade Federal da Bahia \\ Salvador, Bahia, Brasil

\section{MIRELLA MÁRCIA LONGO VIEIRA LIMA²} \\ 2Universidade Federal da Bahia \\ Salvador, Bahia, Brasil
}

Resumo: "Luís Soares" traz à baila as transformações que surgiram na sociedade brasileira a partir da possibilidade de escolha feminina no casamento, independente das imposições familiares e dos fatores que contribuíram para a mudança na mentalidade. Trata-se de uma possibilidade que se abriu lentamente, uma vez que as mulheres tinham suas garantias patrimoniais reduzidas, até mesmo em relação aos bens herdados por elas. $\mathrm{O}$ conto referido é comparado ao romance alencarino Senhora, e são vistas as distinções de tratamento dadas por Machado, já em seus contos iniciais, à posição da mulher na formação do casamento e à possibilidade de redenção pelo amor, bem como a convivência das ideologias burguesa e a senhorial em indivíduos do mesmo grupo social.

Palavras-chave: Machado de Assis; Século XIX; José de Alencar; Literatura Brasileira; Papéis de Gênero.

\section{"LUÍS SOARES," A WOMAN'S CHOICE AND THE NEW OBJECT OF LOVE}

Abstract: "Luís Soares" highlights transformations that appeared in Brazilian society as a result of women's then new freedom to make a choice regarding marriage, regardless of family impositions and the factors that contributed to a change in mindset. This freedom was the result of a gradual shift due to the downsizing of women's guarantees on wealth, including inherited assets. The article compares Machado's early short story to the novel, Senhora, by José de Alencar, and exposes the differences in the writers' treatment of women's position in matrimony and the possibility of redemption through love and the coexistence of bourgeois and manorial ideologies among individuals in the same social group.

Keywords: Machado de Assis; Nineteenth century; José de Alencar; Brazilian literature; Gender roles. 
- Convenho que a pobreza não é cousa agradável, e até acho...

Pires interrompeu-se; uma ideia súbita atravessara-lhe o espírito: a ideia de que Soares acabasse a conferência por pedir-lhe dinheiro. Pires tinha um preceito na sua vida: era não emprestar dinheiro aos amigos. "Não se empresta sangue", dizia ele.

Soares não reparou na frase cortada do amigo, e disse:

- Viver pobre depois de ter sido rico... é impossível.

- Nesse caso que me queres tu? - Perguntou Pires, a quem pareceu que era bom atacar o touro de frente.

- Um conselho.

- Inútil conselho, pois que já tens uma ideia fixa.

- Talvez. Entretanto confesso que não se deixa a vida com facilidade e, má ou boa, sempre custa morrer. Por outro lado, ostentar a minha miséria diante das pessoas que me viram rico é uma humilhação que eu não aceito. Que farias tu no meu lugar?

- Homem - respondeu Pires -, há muitos meios...

- Venha um.

- Primeiro meio. Vai para Nova Iorque e procura uma fortuna.

- Não me convém; nesse caso fico no Rio de Janeiro.

- Segundo meio. Arranja um casamento rico.

- É bom de dizer. Onde está esse casamento?

- Procura. Não tens uma prima que gosta de ti?

- Creio que já não gosta; e demais não é rica; tem apenas trinta contos; despesa de um ano.

- É um bom princípio de vida.

- Nada; outro meio.

- Terceiro meio, e o melhor. Vai à casa de teu tio, angaria-lhe a estima, dize que está arrependido da vida passada, aceita um emprego, enfim vê se te constituís seu herdeiro universal.

Soares não respondeu; a ideia pareceu-lhe boa.

- Aposto que te agrada o terceiro meio? - Perguntou Pires rindo.

- Não é mau. Aceito; e bem sei que é difícil e demorado; mas eu não tenho muitos à escolha. (ASSIS, 1986, p. 46-47)

\footnotetext{
s grandes transformações ocorridas na mentalidade e nos costumes europeus, no século XIX, refletiram-se na produção literária do período. Essas transformações reverberaram também no Brasil com certo atraso, adaptando-se às peculiaridades de nossa formação cultural e histórica. A matéria romanesca, então, alimentava-se da vida burguesa, enfatizando o casamento, o amor e os papéis atribuídos às mulheres e aos
} 
homens. Particularmente, a produção machadiana contemplou alterações ocorridas nos costumes, registrando a passagem do casamento tradicional escolhido e acertado entre os pais e servindo como forma de manutenção de status social e outros interesses familiares - e o casamento moderno - em que entra em cena a eleição dos espíritos, além da seleção realizada pelos próprios indivíduos. Os textos românticos, então, eram tecidos em torno da escolha a ser feita pela mulher, muito mais do que ao redor de um casamento a ela imposto.

É possível flagrar na literatura a passagem da família tradicional e patriarcal (que abrangia todos que viviam numa mesma casa, incluindo criados e empregados) para um núcleo menor e alicerçado na ideia do casal. Nas sociedades tradicionais, o casamento, segundo nos conta Michelle Perrot, é uma "negociação conduzida pelos parentes, pelos amigos, pelos próximos e todos os fatores devem ser avaliados [...] mas as estratégias matrimoniais se diversificam e se tornam complexas. O dinheiro assume formas variadas: móveis, imóveis, negócios e 'esperanças'"' (2010, p. 137). De acordo com Thales de Azevedo, em As regras do namoro à antiga, a escolha conjugal dos filhos, no regime patriarcal, era um privilégio exclusivo do pater familias que visava a "ordem social, a economia, a política e a própria realização pessoal do indivíduo" (1986, p. 7), com base no que o chefe da família acreditava ser o melhor para esse indivíduo.

No Brasil, o pequeno número de famílias abastadas fazia com que alianças fossem criadas para manter as posições financeiras e sociais da família dos noivos. Por tal motivo, era muito comum o casamento entre parentes. Conforme relata June Edith Hahner, no ensaio "Mulheres da elite: honra e distinção das famílias", "os casamentos 'arranjados' facilitavam a manutenção da linhagem e asseguravam a concentração de terras e demais propriedades nas mãos de poucas pessoas e grupos. Também evitavam que estas se dispersassem ao serem divididas entre diversos herdeiros" (2012, p. 48). O costume, no Brasil, assim como em outras partes do mundo, era de que o homem exercesse domínio sobre a mulher e sobre os bens que ela herdava de sua família, pois se entendia que ela era incapaz de administrar suas riquezas. Isso fica evidente, como forma de lei, no Código Filipino - ou Ordenações Filipinas -, que era uma compilação jurídica resultante das reformas que o rei Filipe II fez, quando governou a Península Ibérica, e em substituição ao Código Manuelino.

Na lei e no costume, a ideologia da supremacia masculina prevalecia. Uma mulher passava diretamente da autoridade do pai para a de seu 
marido ao casar-se. O Código Filipino, compilado em 1603 em Portugal e que se manteve efetivo no Brasil até a promulgação do Código Civil de 1916, especificamente designava o marido como "cabeça do casal"; e somente com sua morte a mulher ocuparia a posição de "chefe da casa". Sob a lei civil do século XIX, portanto, as mulheres eram perpetuamente menores. Como esposas elas tinham que se submeter à autoridade do marido em decisões relativas à educação e criação de seus filhos, além da escolha do local de residência. A lei negava às mulheres o direito de comercializar, alienar propriedade imóvel para venda ou arrecadamento, ou mesmo administrar tal propriedade sem o consentimento do marido. As viúvas, entretanto, podiam assumir os negócios da família (como faziam as fazendeiras), pois se esperava que preservassem o patrimônio familiar. (HAHNER, 2012, p. 50)

Em Cenas de amor em romances do século XX, Mirella Márcia Longo Vieira Lima, ao tratar da representação do casamento na literatura realista e em seus desdobramentos mais recentes, focaliza, particularmente, O Delfim, texto publicado, em 1968, por José Cardoso Pires. O comentário da autora sobre o romance do escritor português destaca a existência do "Código Marialva", de largo fôlego mesmo no século XX, em zonas rurais de Portugal. O Marialva é um representante da velha ordem que tem o privilégio de nascimento e, por isso, tem também a necessidade de autoafirmar os atributos que justificariam, em sua ótica, a concessão de privilégios. Entre tais atributos, destaca-se a virilidade. Autoritário e machista quer impor o seu poder e começa por subjugar a mulher - tanto sexual quanto social e moralmente. Para esse tipo social, o adultério era um crime que só condenava as mulheres, para os homens se permitia tudo. Em Portugal, essas bases ideológicas se pautavam no pensamento medieval e preservavam os valores aristocráticos. Nesse ideário que se entranhou na sociedade brasileira, os homens temiam o poder do corpo feminino e buscavam, também por isso, a submissão da mulher e dos filhos ao poder do pai (LIMA, 2017, p. 104-105).

Diversos foram os fatores que provocaram a mudança dessas mentalidades. Dentre eles, como nos conta Angela D'Incao, "a consolidação do capitalismo e o incremento de uma vida urbana que oferecia novas alternativas de convivência social" (D'INCAO, 1997, p. 223). Assim, durante o século XIX, a ascensão da mentalidade burguesa provocou transformações no estilo de vida da sociedade, reorganizando as vivências familiares, domésticas e mesmo a "sensibilidade e a forma de pensar o amor". De todo modo, o casamento entre famílias ricas e burguesas continuou sendo um modo de ascensão e de manutenção do status, embora, agora, a mulher ganhe 
a função de "contribuir para o projeto familiar de mobilidade social" (D'INCAO, 1997, p. 229). Dela passa a depender mais explicitamente a imagem pública da família. O poder ainda pertencia ao marido, mas a mulher é quem cuidava da imagem pública do homem que estava sempre "rodeado por um conjunto de mulheres das quais esperava que o ajudassem a manter sua posição social" (D'INCAO, 1997, p. 230). O bom comportamento feminino e a formação dos filhos nos moldes adequados se refletiam na reputação da família.

Mas, sem dúvida, um novo espaço para a mulher vai sendo aberto nas relações familiares burguesas, que agora passam a valorizar a intimidade entre os cônjuges e a maternidade. A esse respeito, Elisabeth Roudinesco diz que:

Baseada durante séculos na soberania divina do pai, a família ocidental foi desafiada, no século XVIII, pela irrupção do feminino. Foi então que se transformou, com o advento da burguesia, em uma célula biológica que concedia lugar central à maternidade. A nova ordem familiar conseguiu represar a ameaça que esta irrupção do feminino representava à custa do questionamento do antigo poder patriarcal. A partir do declínio deste, cuja testemunha e principal teórico foi Freud ao revisitar a história de Édipo e Hamlet, esboçou-se um processo de emancipação que permitiu às mulheres afirmar sua diferença, às crianças serem olhadas como sujeitos e aos "invertidos" se normalizarem. Esse movimento gerou uma angústia e uma desordem específicas, ligadas ao terror da abolição de diferença entre os sexos, com a perspectiva de uma dissolução da família no fim do caminho". (ROUDINESCO, 2003, p. 11)

Olhando um campo muito amplo, no qual insere a cultura do Ocidente, Roudinesco dividiu a história da família em três fases: a primeira, chamada de "tradicional", é centrada na autoridade do Pai, composta para assegurar a transmissão do patrimônio e realizada através de casamentos arranjados; a segunda, já chamada de "moderna", é baseada na lógica afetiva - iniciada em meados do século XVIII (na Europa), indo até o século XX. Fundada com a divisão do trabalho entre os esposos, a família moderna contemplaria, segundo Roudinesco, o amor romântico, a emersão dos poderes da mulher e do Estado fragilizando o patriarca antes absoluto; e a terceira, a "contemporânea ou pós-moderna", não teria centro de autoridade, mas apostaria em laços fraternos que não coincidem muitas vezes com os laços de sangue. 
Nesse segundo momento, na ordem burguesa, o casamento passa a ser um acordo realizado através do consentimento entre o homem e a mulher, que deveriam privilegiar uma "inclinação espiritual sobre a paixão sexual". E o casamento, como construção alicerçada em afetos, torna-se um dos pilares da sociedade e deixa de ser uma imposição, em que a mulher está totalmente subordinada ao homem. Aliás, o Estado passa a definir papéis, estipulando direitos e deveres. Todavia, mesmo fragilizado, o patriarca mantém o poder. Na visão de Roudinesco, a Modernidade é marcada por essa luta entre os sexos, a era em que o homem se sente permanentemente assaltado pelo fantasma do poder feminino e por isso empreende esforços para assegurar o seu lugar de autoridade. "Pelo trabalho ou pela atividade intelectual, o marido enfrenta o mundo externo com uma reflexão ou sobre o mundo ou sobre si mesmo, ao passo que, no seio do lar, sua esposa, agora mãe, goza de uma liberdade autêntica" (ROUDINESCO, 2003, p. 40). Nessa perspectiva, a figura do pai se aproxima de José, carpinteiro trabalhador. Com isso, a ordem econômica burguesa termina repousando em três fundamentos: a autoridade do marido, ainda que limitada pelo Estado; o controle do corpo da mulher e de seus supostos poderes; e a dependência dos filhos.

No século XIX, no período romântico, ama-se o amor e a ideia de amor. Com isso, propõem-se sentimentos novos, o amor passa a estar mais associado ao estado de alma do que ao contato físico. Enquanto o casamento burguês tem como base o afeto, aquilo que Freud chamou de "a paixão terna", a literatura burguesa exalta a paixão, com sua ardência e seu desrespeito aos limites. Essas duas dimensões se confundem, entretanto, na importância atribuída ao amor. De acordo com Angela D'Incao, no ensaio Mulher e família burguesa, o amor surge como uma epidemia, "uma vez contaminadas, as pessoas passam a suspirar e a sofrer ao desempenhar o papel de apaixonados. Tudo em silêncio, sem ação, senão as permitidas pela nobreza desse sentimento novo"; e isso inclui "suspirar, pensar, escrever e sofrer. Ama-se, então, um conjunto de ideias sobre o amor" (D'INCAO, 1997, p. 234).

Assim, na segunda metade do século XIX, aumentam o número de pessoas que buscam o amor e a felicidade no casamento. De acordo com Thales de Azevedo, no século XIX, o antigo modelo de escolha de cônjuges começa a ser substituído devido às exigências do "amor romântico, ainda que este continuasse a depender bastante das obrigações morais até jurídicas do privatismo familiar e das tradições patriarcais" (AZEVEDO, 1986, p. 08). Assim, elegia-se o candidato ao casamento "pela simpatia, pela atração física, pela correspondência afetiva, tudo subordinado a critérios de estamentos ou 
de classes sociais" (AZEVEDO, 1986, p. 08). Esse modelo começou a ser seguido a partir da "deriva da revolução sexual que ocorreu em fins do século XVIII na Europa" (AZEVEDO, 1986, p. 08). Antes "o sexo e o casamento tinham um objetivo mais social, da comunidade e da família" (AZEVEDO, 1986, p. 08). Essa transformação começou devido ao crescente individualismo, os jovens começaram a dar mais atenção às suas inclinações pessoais e interiores. Mas devido à grande influência dos romances:

Ali pelo ano de 1850 essa tendência se havia fixado, em definitivo, com o surgimento do namoro romântico e o casamento por amor: esses movimentos haviam "privatizado" a família, tendo a felicidade do casal deixado de subordinar-se unicamente aos interesses da família como antes. (AZEVEDO, 1986, p. 8)

Forma literária que melhor representa a Modernidade, o romance influiu diretamente no modo como as mulheres passaram a encarar o casamento e a escolha conjugal. Sem lugar no mercado de trabalho, a mulher burguesa tinha muito tempo livre, que foi ocupado com a leitura de romances; por isso as figuras femininas adquirem máxima importância na história da forma literária, tanto na posição de público consumidor, como no protagonismo que adquirem nas tramas. Na mentalidade da época, as mulheres precisavam ser educadas para se tornarem melhores mães e esposas, para com isso, construir uma sociedade mais evoluída. No entanto, às mulheres também era vedada a educação formal e qualquer aspiração intelectual ou científica, pois seria considerada uma atitude antifeminina. Assim, além da leitura dos romances, foram criadas revistas voltadas ao público feminino visando a educação das mulheres. Embora essas publicações fossem fontes importantes para disseminar um discurso de feminilidade e domesticidade, elas contribuíram para fornecer instrução às mulheres.

Mas a Modernidade se caracteriza pelas contínuas transformações. Mudam-se os gostos e interesses e, assim, muda também o público leitor. A curiosidade e a exigência das leitoras vão ordenando novas formulações e tratamentos aos temas tradicionais. Nas palavras de Werneck Sodré, "ainda os temas tradicionais, que são eternos e que são universais, sofrem modificação de tratamento. Entre os temas tradicionais, esta complicação que leva ao casamento, tudo que leva à família" (SODRÉ, 1982, p. 347).

Em A paixão terna (1990), Peter Gay discorre sobre como as experiências burguesas do amor no século XIX eram espontâneas, mas também socialmente demarcadas, pois a organização social procurava 
moldar as uniões apropriadas. Os caminhos para o amor eram vigiados, por isso, "era comum que aquele que se recusasse ao casamento por dinheiro ou por razões de família, fosse convencido a ir aonde era previsível a presença do dinheiro ou de boa gente de família" (GAY, 1990, p. 09). Não se exclui, portanto, a formação do casal baseada em um sentimento sincero, mas os indivíduos que formavam esse casal já haviam sido conduzidos a locais específicos, onde podiam fazer contatos igualmente específicos e realizar uniões vantajosas.

Contudo, apesar do fato de a Modernidade exaltar o poder da escolha individual, outros fatores continuaram influenciando a constituição matrimonial. Não raro, o casamento nas classes altas se dava, em boa parte, visando o interesse econômico. Assim, o amor e a atração sexual, algumas vezes, não eram tão relevantes, ainda que se quisesse levar o parceiro a crer que existisse um envolvimento romântico. Era comum a separação entre satisfação sexual e os sentimentos que deveriam ser desenvolvidos no seio da família.

Progressivamente, após a Revolução Francesa, o sistema de casamento arranjado deu lugar à aventura amorosa romântica. Na Inglaterra, por exemplo, a escolha do cônjuge já era algo secular e a intromissão dos pais na escolha dos filhos (a princípio) não era vista com bons olhos. Nesse contexto, o namoro era o momento de testar a afinidade e os temperamentos dos pretendentes. Os homens eram aconselhados a não levar em conta a beleza e o dinheiro da noiva.

Sandra Guardini Vasconcelos, em A formação do romance inglês, ao tratar de como a cultura do romance colaborou para a construção do novo ideal feminino, nos diz que:

Com a ascensão da burguesia, a sociedade inglesa havia sofrido mudanças muito significativas. O poder político e econômico começava a mudar de mãos e a combinação de capitalismo e protestantismo determinava novos papéis tanto para o homem como para a mulher, resultando numa nova concepção de casamento. Casamento e amor, que sempre haviam sido mantidos dissociados pela aristocracia, passavam agora a ser vistos como inseparáveis pela burguesia puritana. Com os casamentos de conveniência sendo gradualmente substituídos pelo que o historiador Lawrence Stone chama de "campanionate marriage", a escolha do parceiro tornava-se crucial nesse momento de passagem da família patriarcal para a família conjugal. Passou-se a se revalorizar de modo veemente a fidelidade e a castidade da mulher, que se tornaram mercadoria valiosa no mercado de casamento pois, como afirmou 
Samuel Johnson claramente, eram "da mais alta importância, já que a propriedade depende dela[s]". Delas dependia não só a preservação da propriedade familiar, poderíamos acrescentar, mas principalmente a garantia de descendência legítima. Neste mundo de domínio econômico masculino, as mulheres não tinham direito legal à propriedade nem à riqueza. Todo e qualquer bem que traziam para o casamento, em forma de dote, passavam automaticamente para as mãos do marido. (VASCONCELOS, 2007, p. 124-125)

No Brasil e nos países europeus de cultura latina, o acordo matrimonial ainda estava na mão dos pais e obedecia aos interesses familiares, financeiros e políticos. Sobre os motivos que levam a essa tal tendência no Brasil, Tania Quintaneiro nos diz em Retratos de mulher que:

Entre os fatores culturais e econômicos responsáveis pela tendência a que as brasileiras se casassem mais cedo estariam: a maior sujeição feminina, a procriação como objetivo primordial do matrimônio, a subordinação dos interesses pessoais aos familiares, o que retirava essa decisão da mão das mulheres, o curto intervalo em que recebiam instrução formal, a inexistência de um mercado de trabalho livre e aberto à mão de obra feminina e, em suma, um grau muito reduzido da individualização que acompanha a ênfase nos critérios afetivos para a escolha do cônjuge. (QUINTANEIRO, 1995, p. 55)

Entretanto, esse cenário começa a ser modificado em meados do século XIX, com o aburguesamento da sociedade brasileira e com os novos modelos de vida e de mulher copiados das sociedades europeias e dos romances. Com a maior promoção de eventos sociais na capital brasileira, esperava-se que a mulher da alta sociedade demonstrasse habilidades e talentos para promover a si e a sua família, como "entreter os convidados, conversar polidamente, tocar instrumentos, cantar de modo agradável, demonstrar maneiras refinadas, falar línguas" (HAHNER, 2012, p. 55).

Nessa tentativa de enquadramento ao mundo moderno, a sociedade brasileira se esforça em seguir o modelo de vida burguês, embora haja coexistência de valores e figuras contrastantes e aparentemente opostas à forma de vida burguesa europeia, como a tradição secular do patriarcalismo escravista brasileiro - exemplo disso é o valor atribuído ao trabalho no ideário burguês e na realidade escravocrata nacional.

Em $O$ burguês, Franco Moretti fala sobre os conceitos, a formação e as contradições da classe burguesa, na cultura ocidental. Ele mostra como, a princípio, o trabalho se apresenta como um traço fundamental da cultura 
burguesa e como, em relação à "velha aristocracia", a ideia de trabalho sofre uma descontinuidade. Na Modernidade, o trabalho vai, aos poucos, se tornando uma premissa de legitimação social. Começa-se a considerar a utilidade e a finalidade das coisas, pois, na mentalidade burguesa, tudo que é feito deve ser feito para a utilidade de todos e realizado com eficiência. Essa eficiência significa o poder de fazer de forma adequada e sem desperdício. A propriedade seria, portanto, o trabalho, o suor, o sangue, o esforço. É a construção de uma vida encarnada em cada parede, animal ou árvore.

No Brasil, tal fundamento do trabalho burguês pela eficiência se une tensamente ao seu oposto, assimilando, na prática, padrões do que foi a servidão. A valorização do trabalho e exercício de servidão alicerçam o acúmulo de riquezas das classes privilegiadas. No entanto, no Brasil, a absorção da prática burguesa dá-se lenta e artificialmente devido à manutenção da escravidão. Mesmo assim, Machado de Assis, como veremos a seguir, conseguiu mostrar, ainda em seus primeiros contos, a convivência socialmente problemática entre uma ética superficial de valorização do trabalho e a manutenção de um código senhorial herdado da Colônia.

A criação da cultura do trabalho foi, como se pode argumentar, a maior conquista simbólica da burguesia como classe: o útil, a divisão do trabalho, a "indústria", a eficiência, a "vocação", a "seriedade. [...] O escravismo jamais foi ordenado em torno da noção de eficiência", aponta Roberto Schwarz acerca dos latifúndios brasileiros da época de Conrad, porque podia sempre se apoiar na "violência e na disciplina militar", de modo que "o estudo racional do processo produtivo e sua modernização continuada" eram literalmente "sem propósito". (MORETTI, 2014, p. 49-50)

Em Portugal, no entanto, há uma repulsa à moral fundada no culto ao trabalho, pois se tem apego ao pensamento de que o trabalho é indigno e que boa vida é não fazer nada como um "fidalgo". A ética do trabalho só chega à Península Ibérica com o prestígio de países do Norte e ainda assim encontrando resistência. Há uma exaltação à falta de apreço à atividade utilitária, à digna ociosidade, à vida de grande senhor, sem grande esforço ou preocupação. Por isso, entre as práticas dos povos ibéricos que foram trazidas ao Brasil, havia a solidariedade apenas onde existia vínculo sentimental e a estranheza à obediência, pois não havia uma organização harmoniosa devido à falta de organização racional dos homens em torno do trabalho. Não existia outra forma concebível de obediência, a não ser pela centralização excessiva do poder que se dá através das ditaduras e do Santo Ofício. 
De acordo com Sérgio Buarque de Holanda, em Raízes do Brasil, existem dois conceitos que nos ajudam a melhor situar o conhecimento dos conjuntos sociais que permeiam a sociedade portuguesa/ibérica à época do Brasil Colônia: os tipos ideais do aventureiro e do trabalhador. O homem aventureiro ignora fronteiras e faz do obstáculo um trampolim, suas "energias e esforços se dirigem a uma recompensa inadiada" (HOLANDA, 2004, p. 44). Enquanto que o trabalhador tem esforço lento e persistente, pouco compensador e que primeiro enxerga os obstáculos a serem vencidos. O campo do aventureiro é amplo, o do trabalhador é mais restrito. Ainda de acordo com Sérgio Buarque:

Existe uma ética do trabalho, como existe uma ética da aventura. Assim, o indivíduo do tipo trabalhador só atribuirá valor moral positivo às ações que sente ânimo de praticar e, inversamente, terá por mais detestáveis as qualidades próprias do aventureiro - audácia, imprevidência, irresponsabilidade, instabilidade, vagabundagem - tudo, enfim, quanto se relacione com a concepção espaçosa do mundo, característica desse tipo. (HOLANDA, 2004, p. 44)

Isso nos legou o fato de, no Brasil, durante o século XIX, a atividade profissional ser como um mero acidente ao indivíduo, o que nos opõe a outros países em que a atividade profissional tem quase um acento religioso. Aqui ainda ocorria a persistência da visão que associava trabalhos de "inteligência" às atividades senhoriais, em oposição ao trabalho manual e mecânico que é da classe servil. As profissões liberais alcançaram um alto prestígio no Brasil devido aos fatores de ordem econômica e social. Assim, como em Portugal, as cartas de bacharel valiam muito para conseguir um emprego público. Como nos relata Sérgio Buarque, "não é outro, aliás, o motivo de ânsia pelos meios de vida definitivos, que dão segurança e estabilidade, exigindo, ao mesmo tempo, um mínimo de esforço pessoal, sem aplicação e sujeição da personalidade, como sucede tão frequentemente com certos empregos públicos" (HOLANDA, 2004, p. 157). Isso ocorreu, porque aqui o Estado se tornou "uma ampliação do círculo familiar", não existindo uma gradação entre um e outro, mas uma descontinuidade. O Estado deveria ser, portanto, uma transgressão à ordem doméstica e familiar, mas aqui houve um problema de distinção entre o privado e o público. $\mathrm{O}$ funcionário patrimonial e a gestão pública se apresentam, com os seus interesses particulares. A família excede seu círculo e vai ocupar o espaço público onde deveria existir Estado burocrático.

É nesse contexto que devemos situar o personagem Luís Soares do 
conto homônimo de Machado de Assis, cujo diálogo com o amigo Pires introduziu este ensaio. Ali, Machado narra a história de Luís Soares, rapaz rico e extravagante, que possuía hábitos noturnos, não tinha nenhuma predileção pelo trabalho e gastava largamente a fortuna herdada do pai. Em certo momento, Soares é informado pelo contador que está falido. Como não possui apreço ao trabalho, e até então não havia tido necessidade de desenvolvê-lo, ele pede conselhos ao amigo mais próximo Pires - uma réplica do próprio Soares - para sair da calamitosa situação. Algumas das possibilidades de fuga envolvem esforço e trabalho árduo, o que Soares não estava disposto a fazer. As suas últimas hipóteses envolviam aparentar redenção dos erros cometidos no passado, a fim de se tornar herdeiro universal do tio e/ou conseguir acertar o casamento com a prima Adelaide. $\mathrm{O}$ casamento podia ser descartado. A moça não possuía fortuna suficiente para ele.

Depois de ter se reaproximado da família e conseguido um emprego público por indicação do tio, o major Vilela, Luís Soares, junto aos outros membros da família, descobre que desprezara a herdeira de uma colossal fortuna. Adelaide seria rica. Anselmo, um antigo amigo do pai da moça, a quem a carta e a fortuna foram confiadas, chega à casa da família com a notícia. No entanto, na carta em que é revelada a nova herança, o pai da moça impõe como condição, para o recebimento do dinheiro, que Adelaide se case com o primo Soares. A sugestão é recusada pela mulher, embora ela continuasse apaixonada pelo primo. Para Luís, seria uma nova oportunidade de salvação e, por isso, ele passa a investir em insinuações de amor. Antes da revelação da nova herança, o tio que cuidava de Adelaide, major Vilela, queria impor o casamento entre os dois sobrinhos. Ambos recusaram. Mas o major e Anselmo desistem da ideia de ver os jovens casados, quando Adelaide revela todo o procedimento do rapaz. Na ocasião em que Soares finalmente se declara, Adelaide recusa com veemência a possibilidade de união entre os dois. Na verdade, ela vai muito além da simples recusa, ela o humilha, respondendo com aversão e repulsa: "Adelaide sorriu e soltou lentamente estas palavras: - Trezentos contos é muito dinheiro para comprar um miserável" (ASSIS, 1986, p. 51). Depois disso, partem todos para uma viagem à Europa. Todos, exceto Luís Soares. Ao perceber que havia sido deixado e que só lhe restava o emprego na repartição conseguido através da troca de favores entre o tio e um amigo político, o rapaz tira a própria vida por não suportar a ideia de ser pobre em um mundo que já o vira rico.

Em Confidência mineira: o amor na poesia de Carlos Drummond de 
Andrade, Mirella Vieira Lima se refere ao suicídio por amor como um motivo literário que, percorrendo a literatura ocidental e encontrando, em Werther, de Goethe, o seu apogeu, conquistou lugar destacado em toda a literatura romântica. A análise mostra como esse motivo recebeu, na poesia de Drummond, vigor novo e golpes de ironia. Podemos conceber, no entanto, que essa ironia já aparecera em Machado, embora com feição diferente daquela que apresentou nos versos do poeta mineiro:

Frequente na literatura ocidental, o suicídio do amante frustrado parece ser interpretado por Drummond como uma última tentativa de comunicação, forma de dizer a alguém a intensidade causada pelo fracasso afetivo. Além de gesto extremo, o suicídio seria signo extremo, usado para traduzir a dor amorosa. (LIMA, 2017, p. 46)

Segundo a ensaísta, Drummond questiona não apenas o motivo literário, mas também o suicídio, como linguagem que se torna ineficaz diante da insensibilidade moderna.

Em "Luís Soares", Machado de Assis retoma o suicídio amoroso, mas lhe empresta um novo matiz. Na apresentação do seu amante suicida, há forte denúncia de uma alteração da sensibilidade e das passionalidades vindas do Romantismo. O objeto da paixão amorosa que, em sua intensidade, se torna capaz de levar alguém a encerrar a própria vida não é mais uma pessoa, mas sim o dinheiro e o status social. Luís Soares é, de fato, um amante suicida, mas ele chega ao suicídio por amor ao dinheiro e a sua imagem pública de homem rico. Com isso, Machado critica, por um lado, a persistência de um código senhorial - herdado da Colônia, código esse que tende a ver no trabalho uma fonte de desonras e de humilhações -; por outro lado, Machado denuncia uma mudança na sensibilidade. Em vez do culto à paixão amorosa que, na literatura romântica, conduzia o sujeito aos abismos da sua própria interioridade - assim acentuando o seu conflito com o mundo - há o culto à imagem pública, quer dizer, ao artifício e à máscara social. No caso de Luís Soares, era preciso manter a máscara do homem bem-nascido e afastado do trabalho.

De algum modo, esse conto situado no início da trajetória de Machado toca em questões que mais tarde serão bem elaboradas no conto "O espelho". Como é possível ver no seguinte trecho: "Cada criatura humana traz duas almas consigo: uma que olha de dentro para fora, outra que olha de fora para dentro [...] Shylock, por exemplo. A alma exterior daquele judeu eram os seus ducados; perdê-los equivalia a morrer" (ASSIS, 1986, p. 346). O dinheiro é tão imprescindível a Luís Soares quanto era para a personagem shakespeariana 
d'O mercador de Veneza. No entanto, enquanto Shylock se apega à materialidade imediata dos ducados, Soares atribui ao dinheiro um papel mediador. $\mathrm{O}$ dinheiro lhe garante uma vida de pândego e o mantém longe da humilhação que o trabalho representa. Assim, como para Shylock, também para ele, a pobreza já era meia morte. A sua vida estava tão intimamente ligada à relação com o dinheiro que, ao saber da própria falência, mandou dizer a todos os "amigos" que estava doente, pois não poderia suportar os comentários e olhares de pena no mesmo mundo onde reinara. A despeito dessa mediação, ou talvez por exercê-la de modo agudo, o dinheiro adquire um poder que substitui o da matéria; ou melhor, do corpo. Por isso Pires, o amigo de Luís Soares, tem como preceito de vida não emprestar dinheiro aos amigos, alegando que "não se empresta sangue". Concentrada no protagonista, a paixão pelo dinheiro se generaliza. Uma vez informados de que Soares estava doente, os amigos ficam tristes e consideram que perderiam a companhia de um "grande pândego". Mas não há comoção, quando é dada a notícia de que o homem desfalcado de bens havia tirado a própria vida.

Quanto à sociedade brasileira, pode-se dizer, que tal como representada no conto, está permeada por vários códigos de valores que não convivem sem contradições. O tio de Soares atribui valor ao trabalho e assim entra em choque com a visão de Soares e dos seus amigos interessados na pândega, no gozo alimentado por fortuna farta e em uma vida longe de tudo que possa vir a configurar o mundo do trabalho. De um lado, a penetração de valores burgueses e da Ilustração, com deformação e concessão - afinal, ao ver que o sobrinho trabalhava, o tio planeja introduzi-lo na política, o que não deixa de vir a ser um prêmio que o resgataria -; do lado de Soares, impera o código senhorial mantido no comportamento das elites brasileiras. Para manter a máscara de bem-nascido, Soares deve exibir aversão ao trabalho. Os caminhos que poderiam levá-lo ao dinheiro são a herança ou o matrimônio por interesse. Como dissipara a herança paterna, ele decide buscar outra herança e em seguida o casamento com uma herdeira.

Nesse contexto, o suicídio de Luís Soares não representa uma forma romântica de punição imposta pelo autor para purgar a má conduta de Soares em relação ao amor verdadeiro. Sua morte parece indicar o declínio de um contexto em que se explicita sem pudor o código senhorial herdado da Colônia. A cultura de aversão ao trabalho - prática reservada a escravos, isto é, a seres considerados inferiores - fragiliza-se. A imagem do pândego, que vive de rendimentos, é contraposta à máscara utilizada por Luís Soares 
diante do tio: o trabalhador preocupado com a própria utilidade social e com a política. Por isso, junto a ele, morre também a ideia do casamento imposto pela família. Embora ame Luís Soares, a prima Adelaide recusa se casar com ele, desagradando o tio e desobedecendo ao pai que lhe impusera sua vontade depois de morto. No testamento, o morto decreta que a filha só entrará em posse da herança se casar com Luís Soares. Evidentemente, há aí uma voz do passado, voz que, embora sepulta, deixou seu registro e tenta conduzir a mulher. Mas, como o morto está realmente morto, Adelaide consegue, no novo contexto, manter-se em posse da herança e recusar a vontade paterna. Ela não aceita o arranjo feito em torno de um patrimônio. Em alguma medida, Luís Soares termina por concentrar em si a angústia do homem livre e pobre numa sociedade que reserva o trabalho para escravos. Nesse sentido, o conto evidencia a falta de saída. A morte de Luís Soares é um sinal da nova ordem que tenta se estabelecer em um terreno movediço, onde ainda há senhores e escravos e já circulam ideias liberais.

No início do conto, é dito que Soares não tem coração. De fato, ele mesmo se descrevia como alguém que nasceu "com a grande vantagem de não ter cousa nenhuma dentro do peito nem dentro da cabeça. Isso que chamam juízo e sentimento são para mim verdadeiros mistérios. Não os compreendo porque os não sinto" (ASSIS, 1986, p. 44). Depois de ter comunicado a morte de Soares, seu amigo, Pires, comenta que vai ao Alcazar assistir ao Barbe-Bleue. É mesmo possível associar Luís Soares ao personagem trazido à letra por Charles Perrault, uma vez que o Barba Azul, também não possuía coração, pois havia matado várias esposas, morre depois que sua nova esposa descobre seu segredo. Ambos pertenciam às elites. A esposa do Barba Azul usa o dinheiro que lhe foi legado com a morte do marido para tentar se restabelecer do suplício do casamento. Da mesma forma, por sugestão de Anselmo, o testamenteiro de seu pai, Adelaide viaja para Europa para aproveitar a nova fortuna, com a diferença de que ela consegue escapar antes do casamento.

Machado claramente nos mostra a natureza dupla do grupo de Luís Soares. Esse grupo acolhe os modismos e as veleidades vindas da Europa. Por outro ângulo, esse mesmo grupo manifesta afinidade com o código senhorial que mantém a aversão ao trabalho e, ligada a ela, a mão de obra escrava. Na ideologia senhorial, a vontade do chefe da família é inviolável, é ela que vai organizar as relações sociais daqueles que os rodeiam. A manifestação máxima dessa vontade é o testamento, que deveria dar continuidade ao poder de proprietário inerente ao Senhor, mesmo depois de sua morte. Não é 
o que ocorre na trama machadiana.

O conto de Machado surgiu numa revista em 1869. Em 1870, passou a integrar o livro Contos fluminenses. Muitos dos aspectos por ele tratados - o casamento por interesse, a compra de um marido etc. - foram retomados por José de Alencar em Senhora, romance que veio a público na forma de folhetim, em 1874. Em seu tão conhecido romance, Alencar retrata os problemas que envolvem o casamento por interesse e o amor. Aurélia Camargo é órfã e vê-se abandonada pelo homem a quem amava, pois é pobre e não possui dote. Ela é a filha mais nova de um casal que se formou a contragosto de suas famílias. A mãe fugira para conseguir casar com Pedro Camargo, que, por sua vez, era filho bastardo de um rico fazendeiro. Com medo de retaliações do pai, Pedro esconde o casamento e o nascimento de seus dois filhos. Quando o avô de Aurélia resolve reconhecer a família do filho, a neta já é órfã, havia perdido o irmão e fora acolhida na casa de uma vizinha. Ao receber a fortuna do avô, Aurélia, primeiro, é cobiçada pela família do tio materno, que até então não tinha relações com a prole da irmã. Ao descobrir a existência da sobrinha, Lemos trata de tentar "agenciá-la". No entanto, ao contrário do que ocorre com muitos personagens no Romantismo, Aurélia demonstra autonomia de pensamento e de ação. Ela controla não só o dinheiro, mas a própria vida. Isso fica explícito em sua recusa em ir morar com a família do tio, quando a mãe morre e todos descobrem que ela tinha herdado uma fortuna do avô. Para libertar-se, Aurélia é capaz de chantagear o seu tio, usando uma carta comprometedora que ele havia lhe enviado.

Assim, demonstrando ter adquirido enorme capacidade de cálculo, a partir das experiências negativas que a vida lhe impusera, Aurélia usa Lemos como títere de suas vontades e instrumento para realizar seus planos. Ao mesmo tempo em que se protege de uma sociedade que não vê com bons olhos quaisquer escolha e voluntarismo vindos de uma mulher.

O tratamento romantizado que Alencar dá a suas personagens e narrativas faz com que Aurélia e a Adelaide, de Machado de Assis, difiram, apesar de ambas acreditarem que o casamento deva ser feito por amor. Aurélia usa sua herança para se vingar de Seixas por tê-la abandonado. No entanto, o casamento se constitui num caminho que redime Seixas de seus erros. Para Alencar, o amor é uma via de salvação, sendo capaz de transformar um homem venal e corrupto - visto que Seixas era um funcionário que recebia para favorecer alguns projetos e havia trocado Aurélia por um casamento com Adelaide Amaral - em alguém com valores, 
que estima o trabalho sério e que é capaz de amar sem pensar nas recompensas financeiras. A vingança da mulher apaixonada e ferida opera um movimento de redenção. Justamente, quando Seixas se redime e prova não ter mais interesses na fortuna de Aurélia, é recompensado com a revelação de que se tornara o herdeiro universal da esposa.

Ao analisar o romance de Alencar, Roberto Schwarz o contextualiza a partir do surgimento desse gênero literário no Brasil e traça paralelos com os moldes estrangeiros. Assim, ele nos diz que o romance no Brasil surge copiando o molde europeu, mas os pressupostos dessa forma estavam fora de nossa realidade. A adoção da forma romance implicaria, em sua ótica, adotar também a ideologia que a gerou e que entrava em choque com a nossa formação social. Da mesma maneira, "caberia ao escritor, em busca de sintonia, reiterar esse deslocamento em nível formal, sem o que não fica em dia com a complexidade objetiva e sua matéria - por próximo que esteja de lição dos mestres. Esta será a façanha de Machado de Assis" (SCHWARZ, 2012, p. 36).

Segundo Schwarz, o romance brasileiro, seu estilo e seu tom estavam sendo descobertos. Também na Europa - ele observa - seus temas não estiveram prontos desde sempre, mas foram surgindo com as modificações da sociedade. No Brasil, eles haveriam de sofrer alterações: "os grandes temas, de que vem ao romance a energia e nos quais se ancorava a sua forma - a carreira social, a força dissolvente do dinheiro, o embate de aristocracia e vida burguesa, o antagonismo entre amor e conveniência, vocação e ganhapão" (SCHWARZ, 2012, p. 38). Ao falar de Alencar, Schwarz observa que, em muitas de suas obras, ele trará a versão realista do romance e, em outras poucas, o enredo encontra "a sua mola nas ideologias do destino romântico". A trama que traz a mistura do local com o ideal europeu não poderia ter uma resolução simples, pois isso o torna incompatível com o contexto brasileiro, "uma incongruência central em nossa vida pensada". Schwarz ainda diz que na literatura é necessário analisar caso a caso, porque:

Literatura não é juízo, é figuração: os movimentos de uma reputada chave que não abra nada tem possivelmente grande interesse literário. Veremos que em Machado de Assis a chave será aberta pela fechadura. [...] O registro sobe quando passamos ao círculo mundano, limitado, aliás, à mocidade casadoura - o que tem seu interesse, como se verá. Aqui presidem o cálculo do dinheiro e das aparências, e o amor. (SCHWARZ, 2012, p. 42-43)

Como se vê, Roberto Schwarz comenta um desafio imposto ao 
romancista brasileiro. Trata-se da necessidade de expressar uma contradição inerente à adoção da forma romance, com seu leque temático, a representação de uma realidade - a nacional - que permanece à distância da matéria histórica que corresponde à forma. Segundo Schwarz, Alencar não tem êxito na expressão dessa contradição. A rotina dos personagens de Senhora, ele observa, é constituída por hipocrisia combinada à pretensão de exemplaridade e à espontaneidade do sentimento romântico. Assim, o dinheiro é a mediação das relações sociais e pessoais que enxerga os homens como mercáveis; a pureza e a moralidade são os modelos convencionais: "falta complexidade a seus polos. A riqueza fica reduzida a um problema de virtude e corrupção, que é inflado, até tornar-se a medida de tudo" (SCHWARZ, 2012, p. 43).

Resumindo, digamos que em Senhora a reflexão toma o alento e a maneira à esfera mundana, do dinheiro, da carreira, dando-lhe por conseguinte a primazia na composição. Como as grandes personagens da Comédia Humana, Aurélia vive o seu dilaceramento e procura expressá-lo, transformando-o em elemento intelectual da existência comum, e em elemento formal - como se verá, a propósito do enredo responsável pelo fechamento do romance. No entanto, esse tom reflexivo e problemático, bem realizado em si mesmo, não convence inteiramente, e é infeliz em seu convívio com o outro. Faz efeito pretensioso, tem alguma coisa descabida. (SCHWARZ, 2012, p. 44)

Alencar, então, copia a sociedade brasileira, que por sua vez copia a sociedade europeia, mas faz isso à maneira da Europa, sem a crítica necessária para que esse procedimento de composição faça sentido em nossa realidade. São flagrados desajustes entre postura e dicção que "não assentavam nas circunstâncias locais". Ao comparar Alencar e Machado, o ensaísta observa que o segundo tira partido desses desajustes, trazendo o que é periférico para o canto do romance e afetando a "grandiloquência séria". Nas palavras de Schwarz:

Em Senhora, a cor local desacredita o nó dramático, em que se implicava a nova civilização do Capital. Inversamente, na primeira fase machadiana, mesmo escassa e filtrada, a cor moderna dá contraste, e se faz sensível a estreiteza do conflito central, em que rearranjos na esfera doméstica fazem figura de solução de conflitos sociais. Conforme anunciávamos, o acessório realista de Alencar tornou-se força formal e as audácias cosmopolitas de seu conflito central reduzem-se ao que no fundo sempre foram, elementos da moda. (SCHWARZ, 2012, p. 85-86) 
Por outro lado, João Luiz Machado Lafetá (2004) defende a forma como Alencar constrói Aurélia e a narrativa de Senhora, afirmando que é necessário entrar na história e entender o sistema social e ideológico que a produziu. Lafetá cita Antonio Candido que postula a existência de três Alencares: o primeiro que traz a idealização de grandes heróis nacionais; o segundo que se centra no enredo sentimental; e o terceiro que é o "explorador habilidoso dos conflitos entre sentimentos e ascensão social, dos desníveis entre o passado culposo e o presente repleto de promessas, das desarmonias geradas pelo choque entre o Bem e o Mal, pelos desvios do equilíbrio supostamente natural" (LAFETÁ, 2004, p. 424). Para defender o seu ponto de vista, Lafetá observa que o romance de Alencar se apoia sobre bases míticas, utilizando figuras "obsessivas" que povoam a dimensão mítica da ficção romântica, nela encontrando recorrência. Tais imagens, em acordo com Lafetá, retornam, ditando e dando unidade à obra de Alencar. Entre esses motivos estão "a castidade, o amor total, o beijo que revive, o altruísmo, a dedicação incondicional e a morte libertadora" (LAFETÁ, 2004, p. 425). Assim, ao contrário de Schwarz, cujos focos recaem sobre a dimensão realista da trama, Lafetá analisa Senhora através das suas figuras arquetípicas inerentes ao modo mítico. Trata-se, efetivamente, daquilo que Frye chama de "mito deslocado". Segundo Lafetá, sem o deslocamento, Alencar teria chegado a imagens puras que opõem o Paraíso (lugar da felicidade), ao Inferno (reino da dor e da confusão). A hipótese interpretativa do crítico mineiro sustenta que o mito se apresenta na obra de Alencar, após o deslocamento que, nas tendências realistas, o aproxima das "regras de verossimilhança". Dessa forma, a obra, ainda que encarnada em lugar e período histórico determinados, dirige-se à "descrição da experiência humana". Há, então, o choque entre o mundo do amor idealizado com outro mundo, sob o domínio do dinheiro - fator de degradação das pessoas e das suas relações. Esse choque se concentra em Aurélia, debatendo-se entre dois espaços, "aquele do desejo, da inocência e do amor, e outro, ironicamente invertido, da repulsa e da objeção" (LAFETÁ, 2004, p. 428). Apesar da vida em sociedade que é "movida pelo interesse e pelo ouro, metal degradado de sua nobreza e transformado em dinheiro, cotação e mercado" (LAFETÁ, 2004, p. 429), Aurélia não se deixa contaminar, conseguindo se manter pura, a despeito das "tentações". Aurélia é comparada por Lafetá à imagem da Virgem Maria, lutando contra a serpente da sociedade, do dinheiro e das corrupções. É através dela que Seixas consegue alcançar a salvação. Apoiado nas leituras de Frye, ele afirma que "essa contradição podemos chamar de 
conflito entre os mundos da inocência e da experiência. [...] A direção de nossa leitura: as imagens do romance compõem uma estrutura apoiada sobre forte substrato mítico, que aflora a cada instante". (LAFETÁ, 2004, p. 430).

São dois modos de ler um mesmo enredo. Com olhos fixos na representação da sociedade brasileira, Schwarz, em Alencar, acusa o falseamento dessa realidade e a elipse das suas contradições. Machado, mesmo nos contos e romances iniciais, já seria, segundo Schwarz, fortemente ligado à realidade brasileira e aos seus paradoxos, que são transportados para a composição, como elementos formais. Já Lafetá, focalizando o substrato mítico do romance alencariano, vê, na trama de Senhora, a representação de uma experiência humana. Os dois leitores de Alencar permanecem silenciosos acerca da questão da mulher e é justamente por essa via que o romance alencariano pode ser posto em diálogo com "Luís Soares", o conto machadiano.

Talvez Adelaide não tente salvar ou redimir Luís Soares, por saber que nele não há essa possibilidade. Ainda que eivada de romantismo, essa prosa inicial de Machado de Assis já abre espaço para a mulher mais consciente de si própria e ávida pela possibilidade de conduzir o seu próprio destino. Assim, a personagem feminina não incorpora a fantasia de redenção do outro - o homem -, mas se volta para a construção do seu próprio caminho. Em diversos romances de Alencar, a redenção é possível. Assim foi com Lúcia e assim ocorreu com Seixas. Aurélia tem a natureza quixotesca e tenta lutar contra uma sociedade corrompida e educada a viver das aparências com relações artificiais.

O ponto de encontro das duas narrativas está no fato de, tanto numa, como noutra, as mulheres ganharem espaço e poder para manipular dentro de suas possibilidades a realidade em que viviam. Adelaide, ainda que de forma moderada, foi contestadora da vontade senhorial, não admitiu se curvar, preferindo abrir mão de sua herança a ter que viver com alguém que a desprezava e que só passa a nutrir interesse por ela, tendo como único objetivo o seu dinheiro. Aurélia, por sua vez, utiliza o dinheiro que herdou para comprar respeito, casamento, vingança e afeição - porque só o dinheiro possibilitou que ela oferecesse um dote tão alto a Seixas. Importa pouco se, ao final, ela decide se curvar. Curva-se por vontade própria.

Em "Luís Soares", há expressão da vontade feminina. Em Senhora, Aurélia realmente faz jus ao seu poder de soberana na opção do casamento, pouco importa que, no final, ela ceda ao idealismo romântico e, por vontade própria e culto ao sentimento amoroso, conceda poder ao marido. Os dois 
autores representam a interferência do dinheiro nas relações sociais. E, embora ainda possua, nesses primeiros contos, forte influência romântica, Machado de Assis constrói a trama de Luís Soares com aguda percepção das contradições inerentes à sociedade brasileira e às relações familiares.

\section{Referências}

ALENCAR, José de. Senhora. Rio de Janeiro: Nova Fronteira, 2016.

ASSIS, Machado de. Contos Fluminenses. In: Obra completa. Rio de Janeiro: Nova Aguilar, 1986. v. II (Biblioteca luso-brasileira. Série brasileira).

AZEVEDO, Thales de. As regras do namoro à antiga: aproximações socioculturais. São Paulo: Ática, 1986. (Ensaios 118)

Código Philipino, ou, Ordenações e leis do reino de Portugal: recopiladas por mandado d'El-Rey D. Philippe I. Disponível em: <http://www2.senado.leg.br/bdsf/item/id/242733>. Acesso em: 27 jan. 2018.

D'INCAO, Maria Angela. Mulher e família burguesa. In: DEL PRIORE, Mary. (Org.); BASSANEZI, Carla. (Coord. de textos). História das mulheres no Brasil. 2. ed. São Paulo: Contexto, 1997. p. 223-240

GAY, Peter. A paixão terna: a experiência burguesa da rainha Vitória a Freud. Trad. Sérgio Flaksman. São Paulo: Companhia das Letras, 1990.

HAHNER, June Edith. Mulheres da elite: honra e distinção das famílias. In: PINSKY, Carla Bassaneli; PEDRO, Joana Maria (Org.). Nova história das mulheres no Brasil. São Paulo: Contexto, 2012 p. 43-64.

HOLANDA, Sérgio Buarque de. Raízes do Brasil. 26. ed. Companhia das Letras: São Paulo, 2004.

LAFETÁ, João Luiz. As imagens do desejo. In: A dimensão da noite e outros ensaios. São Paulo: Duas Cidades; Editora 34, 2004. p. 337-393

LIMA, Mirella Márcia Longo Vieira. Dos casamentos. In: Cenas de amor em romances do século XX. Salvador: Quarteto, 2017. p. 91-156 . Confidência mineira: o amor na poesia de Carlos Drummond de Andrade. São Paulo: EDUSP; Campinas/Pontes, 1995.

MORETTI, Franco. O burguês: entre a história e a literatura. Trad. Alexandre Morales. São Paulo: Três Estrelas, 2014.

PERRAUlT, Charles. Barba Azul. Trad. Tamara Queiroz. Editora Wish, 2013. Disponível em: <http://cabana-on.com/Ler/wpcontent/uploads/2017/09/Charles-Perrault-Barba-Azul.pdf >. Acesso em: 20/11/2019.

PERROT, Michelle. História da vida privada: da Revolução Francesa à Primeira Guerra. Trad. Denise Bottmann e Bernardo Joffily. 2. ed. v. 4. São Paulo: Companhia das Letras, 1991. 
QUINTANEIRO, Tania. Retratos de mulher: o cotidiano feminino no Brasil sob o olhar de viageiros do século XIX. Petrópolis: Vozes, 1995.

ROUDINESCO, Elisabeth. A família em desordem. Trad. André Telles. Rio de Janeiro: Zahar, 2003.

SCHWARZ, Roberto. Ao vencedor as batatas: forma literária e processo social nos inícios do romance brasileiro. 6. ed. São Paulo: Duas Cidades; Editora 34, 2012.

SODRÉ, Nelson Werneck. História da literatura brasileira. 7. ed. São Paulo: Difel, 1982.

VASCONCELOS, Sandra Guardini Teixeira. A formação do romance inglês: ensaios teóricos. São Paulo: Aderaldo \& Rothschild; Fapesp, 2007.

NAIARA SANTANA PITA é mestre em Literatura e Cultura pela Universidade Federal da Bahia, com dissertação intitulada Dinheiro, amor e casamento: a formação do par amoroso em Contos fluminenses e Histórias da meia-noite de Machado de Assis. Graduada em Letras Vernáculas com Língua Inglesa pela Universidade Federal da Bahia.

(D) http://orcid.org/0000-0003-2502-5442. E-mail: naipita@hotmail.com

MIRELLA MÁRCIA LONGO VIEIRA LIMA é doutora em Teoria Literária e Literatura Comparada pela Universidade de São Paulo. Professora Titular de Teoria Literária e Literatura Comparada, atua nos cursos de Graduação e no Programa de Pós-Graduação em Literatura e Cultura do Instituto de Letras da Universidade Federal da Bahia (UFBA). Bolsista nível 2 do CNPq. Publicou Cenas de amor em romances do século XX, Um quarto muito amplo: memorial acadêmico e Confidência mineira: o amor na poesia de Carlos Drummond de Andrade, entre outras publicações.

(D) https://orcid.org/0000-0003-4186- 0720. E-mail: mirella@ufba.br

Recebido: 07.03.2020

Aprovado: 28.04.2020 